\title{
AN ASSOCIATION BETWEEN RAINFALL AND SEX RATIO IN MAN
}

\author{
W. R. LYSTER AND MARGUS W. H. BISHOP \\ Department of Primary Industry, Bureau of Agricultural Economics, \\ Canberra, A.C.T., Australia, \\ and Department of Animal Husbandry, University of Bristol, \\ Langford, Bristol
}

(Received 1st September 1964)

\begin{abstract}
Summary. Seasonal variations in secondary sex ratio in man in Perth, Adelaide and Brisbane appear to be influenced by seasonal variations in rainfall. In these cities, the onset of the rainy season is followed about 11 months later by a larger than normal excess of male births. Sex ratio in Sydney, however, where rainfall is more evenly distributed throughout the year, does not vary markedly with season; but a relationship between rainfall and sex ratio again becomes apparent when the data are analysed in terms of wet months and dry months and of wet years and dry years. It is suggested that secondary sex ratio is affected by properties of drinking water that alter with variations in rainfall, and that the property of water concerned is probably its content of trace elements. Support for this hypothesis has been obtained from an examination of sex ratios in two regions of Australia with trace-element deficiencies. It is also suggested that drinking water exerts its effect through the male parent and that the observed variations in secondary sex ratio reflect similar variations in primary sex ratio.
\end{abstract}

\section{INTRODUCTION}

In mammals, sex is genetically determined at fertilization and depends upon whether the fertilizing spermatozoon carries an $\mathrm{X}$ (female-determining) chromosome or a $\mathrm{Y}$ (male-determining) chromosome. For convenience, the two kinds of spermatozoa can be referred to as X- and Y-spermatozoa. In theory, meiosis during spermatogenesis ensures that $\mathrm{X}$ - and $\mathrm{Y}$-spermatozoa are produced in equal numbers; hence, if each kind is equally competent to reach and fertilize the eggs, the sex ratio at fertilization (the primary sex ratio) will be unity. If male and female zygotes are equally viable in utero, the sex ratio at birth (the secondary sex ratio) will also be unity.

In man, secondary sex ratio in most countries displays a slight excess of males: in Australia, among live births, there are about 105.3 males to 100 females; in England and Wales there are about 105.8 males to 100 females. There is also evidence that this ratio varies systematically in different populations of births. Variation of this kind has been claimed, for example, between 
births of different birth order, between legitimate and illegitimate births, between births at different seasons, between births in different countries and regions of the same country, between different social classes and different races, between births in rural areas and those in urban areas, and between births in time of war and those in time of peace (see Crew, 1952; Colombo, 1957). Some of these differences have been claimed to be statistically significant, but often other observations have given rise to contrary findings and in no case has a causal influence on sex ratio variation been unequivocally demonstrated. It is widely believed, however, that variation in secondary sex ratio reflects variation in the greater susceptibility of males to prenatal death rather than variation in primary sex ratio. According to this view, higher incidences of prenatal death are associated with higher losses among males than among females, and hence with lower secondary sex ratios. Some workers, however, believe that the determination of primary sex ratio is to some extent labile and that variations in secondary sex ratio reflect this lability. Both beliefs suggest that the primary sex ratio, which unfortunately cannot be measured, must depart from unity in favour of an excess of males, and this implies that Yspermatozoa are either more effective in fertilizing eggs, or are produced in greater numbers, than X-spermatozoa. Natural selection will, of course, tend to ensure that the sex ratio will be optimal, presumably unity, at reproductive age, and if one sex is more vulnerable than the other during prepuberty a compensating adjustment in primary sex ratio is to be expected.

This paper gives evidence of systematic fluctuations of secondary sex ratio in Australia that appear to be associated with variations in rainfall. It is suggested that the rains influence sex ratio by altering the properties of drinking water, and that the content of trace elements is the property most likely to be involved. Evidence consistent with this thesis has been obtained by an examination of sex ratios in two areas of Australia with known trace element deficiencies. It is also suggested that the rains (or trace elements) exert their effect on sex ratio through the male parent, and that the observed variation in secondary sex ratio reflects variation in primary sex ratio.

\section{SOURCES OF INFORMATION}

The figures of monthly rainfall for Perth, Adelaide, Brisbane and Sydney, given in Table 1, have been taken from the 1961 edition of the Yearbook of the Commonwealth of Australia (Government Printer, Canberra). Rainfall for these areas has changed but little since 1941, and the 30-year averages for 1911 to 1940 are still accepted as the official averages. Information on rainfall used in compiling Table 7 was taken from the unpublished monthly readings for the Cordeaux Dam for the years before 1941, and from the weighted average for the whole catchment area compiled by the Metropolitan Water Board of Sydney for later years. With the exception of 1961, the rainfall registrations used in Table 8 are from the Yearbook of the Commonwealth of Australia: those for 1961 were obtained from the Commonwealth Bureau of Meteorology. These figures relate to Sydney itself and not the whole catchment area.

The monthly live birth registrations for Perth, Adelaide, Brisbane and Sydney, given in Tables 2, 3, 4, 6 and 7, are from unpublished figures provided 
by the Commonwealth Statistician, Canberra. These registrations actually relate to the Metropolitan Divisions of Western Australia, South Australia, Queensland and New South Wales respectively: in each case the town contains most of the people in the Division. In Australia, registrations must be made within 60 days of birth and are not corrected for the actual date of birth; but, since certain social service benefits cannot be claimed before registration, the average delay between birth and registration probably is not more than 2 or 3 weeks. (Months in which public holidays fall, do, however, tend to show fewer births than full working months.) Only live births have been considered because figures for stillbirths are not available except for larger areas than this study deals with. (The incidence of stillbirths in the whole of Australia is now about 1.4\%. According to the Statistical Register for New South Wales, the incidence of stillbirths in the State of New South Wales for the 10 years 1951 to 1960 was $1.6 \%$, with a sex ratio of 114 males to 100 females.) The annual birth registrations for Brisbane and Sydney, used in Tables 5, 9 and 10, are from appropriate numbers of the Bulletin of Demography (Bureau of Census and Statistics, Government Printer, Canberra). The birth registrations used in Table 11 are from various issues of the Statistical Register for New South Wales (Government Printer, Sydney).

The significance of differences between estimates of sex ratio was determined by the chi-squared test.

TABLE 1

AVERAGE MONTHLY RAINFALL FOR PERTH, ADELAIDE, BRISBANE AND SYDNEY FOR THE YEARS 1911 TO 1940

\begin{tabular}{|c|c|c|c|c|}
\hline & \multicolumn{4}{|c|}{ Rainfall (in.) } \\
\hline & Perth & Adelaide & Brisbane & Sydney \\
\hline $\begin{array}{l}\text { January } \\
\text { February } \\
\text { March } \\
\text { April } \\
\text { May } \\
\text { June } \\
\text { July } \\
\text { August } \\
\text { September } \\
\text { October } \\
\text { November } \\
\text { December }\end{array}$ & $\begin{array}{l}0.33 \\
0.50 \\
0.90 \\
1.75 \\
5.14 \\
7.55 \\
7.08 \\
5.78 \\
3.37 \\
2.30 \\
0.75 \\
0.54\end{array}$ & $\begin{array}{l}0 \cdot 76 \\
1 \cdot 10 \\
0 \cdot 87 \\
1 \cdot 45 \\
2 \cdot 49 \\
2.93 \\
2 \cdot 49 \\
2.58 \\
2 \cdot 39 \\
1.54 \\
1.22 \\
1 \cdot 27\end{array}$ & $\begin{array}{l}5 \cdot 72 \\
5 \cdot 47 \\
4 \cdot 97 \\
3 \cdot 68 \\
2 \cdot 35 \\
2 \cdot 75 \\
1 \cdot 88 \\
1 \cdot 07 \\
1 \cdot 69 \\
2 \cdot 27 \\
4 \cdot 00 \\
4 \cdot 24\end{array}$ & $\begin{array}{l}3 \cdot 86 \\
3 \cdot 15 \\
4 \cdot 44 \\
5 \cdot 65 \\
4 \cdot 98 \\
3 \cdot 68 \\
4 \cdot 89 \\
2 \cdot 41 \\
2 \cdot 77 \\
2 \cdot 80 \\
2 \cdot 54 \\
3 \cdot 63\end{array}$ \\
\hline Mean & 3.00 & $1 \cdot 76$ & $3 \cdot 34$ & $3 \cdot 73$ \\
\hline
\end{tabular}

Perth, Western Australia

\section{OBSERVATIONS}

Rainfall in Perth varies with season in a striking and predictable manner (Table 1, Text-fig. 1). The opening rains of the wet season begin in mid-April, when water supplies are at their lowest, and immediately create a high degree of turbidity (suspended matter) in the reservoirs. By the end of July, only the heaviest falls of rain can cause as much turbidity as a moderate fall in April. 
The aggregated monthly registrations of live births for the period 1941 to 1962, classified according to sex, are set out in Table 2. The sex ratio for the months of March, April and May combined is significantly higher $(P<0.01)$ than that for the rest of the year. The month of conception for each sex ratio figure can be approximately determined by deducting 9 months from the month of birth registration. This adjustment shows that the high sex ratios result from conceptions in June, July and August, a period which extends from about

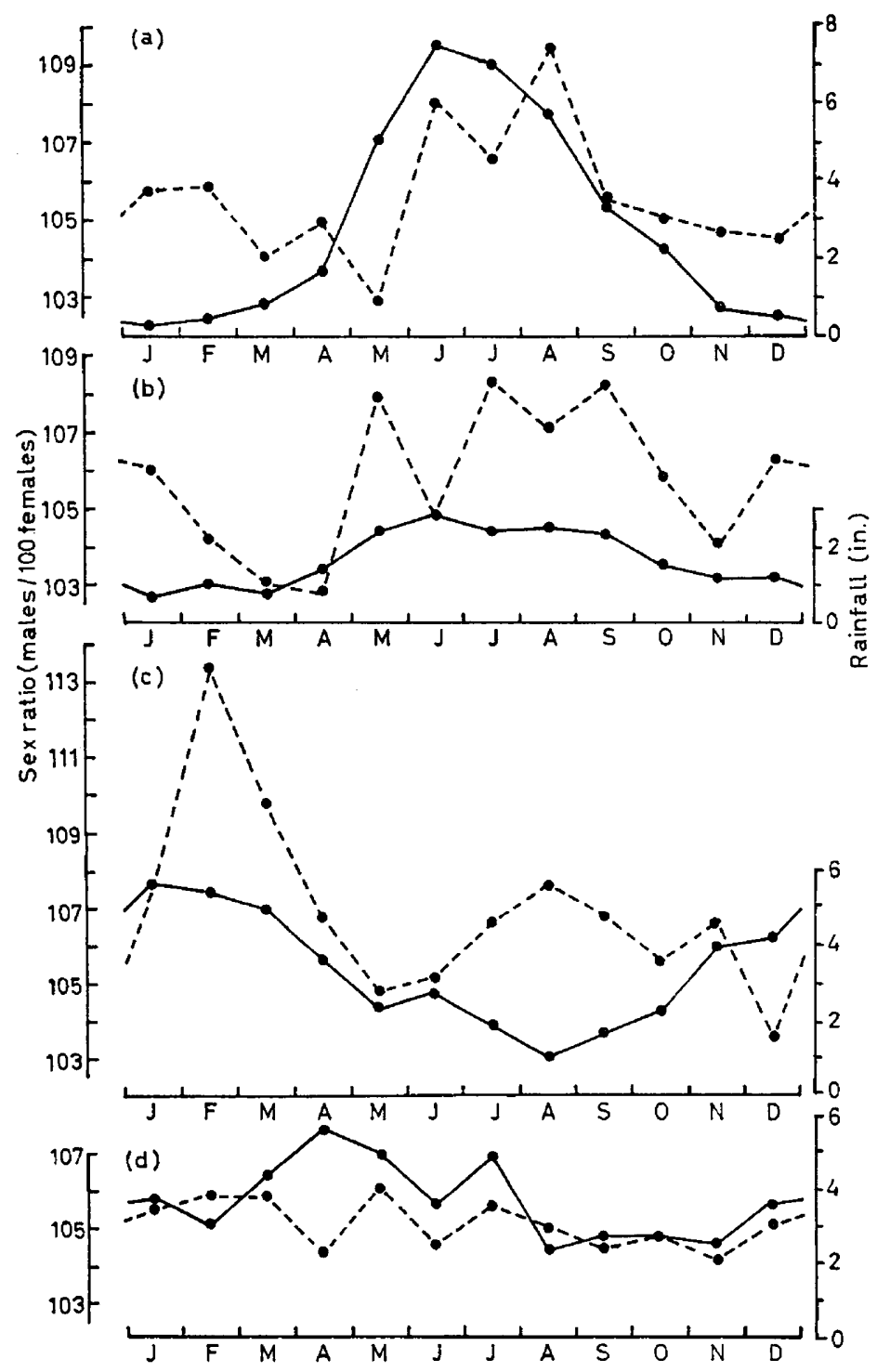

Text-Fig. 1. The monthly distribution of rainfall (solid lines), and of sex ratio at birth plotted at month of conception (broken lines), for (a) Perth, (b) Adelaide, (c) Brisbane and (d) Sydney. The data are taken from Tables 1, 2, 3, 4 and 6. 
6 weeks to about 18 weeks after the onset of the wet season (Text-fig. 1). This seasonal variation in sex ratio is not associated with seasonal variation in total birth registrations, which are highest in October (conception month, January), although February (conception month, May) has both the lowest sex ratio and birth registration figures. Before 1940, however, there were no clear seasonal trends; until this time, Perth drew a large proportion of its drinking water from deep (2000 ft) artesian bores in limestone formations, and such water is likely to differ considerably from that obtained by surface drainage.

\section{TABLE 2}

AGGREGATED MONTHLY REGISTRATIONS OF LIVE BIRTHS FOR THE METROPOLITAN DIVISION OF WESTERN AUSTRALIA $\dagger$ FOR THE YEARS 1941 TO 1962

\begin{tabular}{l|c|c|c}
\hline & Male births & Female births & $\begin{array}{c}\text { Sex ratio } \\
\text { female }=100)\end{array}$ \\
\hline January & 6510 & 6198 & $105 \cdot 03$ \\
February & 6115 & 5937 & $103 \cdot 00$ \\
March & 6491 & 6004 & $108 \cdot 11^{*}$ \\
April & 6593 & 6183 & $106 \cdot 65^{*}$ \\
May & 7277 & 6649 & $109 \cdot 44^{*}$ \\
June & 6566 & 6221 & $105 \cdot 55$ \\
July & 6765 & 6440 & $105 \cdot 05$ \\
August & 7051 & 6738 & $104 \cdot 67$ \\
September & 6851 & 6553 & $104 \cdot 55$ \\
October & 7624 & 7209 & $105 \cdot 76$ \\
November & 6807 & 6431 & $105 \cdot 84$ \\
December & 6489 & 6232 & $104 \cdot 12$ \\
Total & 81139 & 76795 & $105 \cdot 66$ \\
\hline
\end{tabular}

$\uparrow$ Perth is the largest component of this division.

* The sex ratio for these months combined differs significantly from that of the other 9 months $(P<0 \cdot 01)$.

\section{Adelaide, South Australia}

Adelaide also has a highly predictable seasonal variation of rainfall, but here the wet season usually starts at the beginning of May, and the total rainfall is much lower than at Perth (Table 1, Text-fig. 1). The catchment area for Adelaide's water supply was uniform until 1955, when considerable supplementation from the river Murray was started. This is a very large river which, with its tributary the Darling, drains a vast area of south-eastern Australia.

The aggregated monthly registrations of live births from 1911 to 1955 show a significantly higher sex ratio $(P<0.01)$ for the months of February, April, May and June than for the rest of the year (Table 3 ). The lowest sex ratio was recorded for January. The conception months for high sex ratio are May, July, August and September, of which the last three extend from about 8 weeks to about 20 weeks after the onset of the rainy season (Text-fig. 1). The high sex ratio for February is anomalous in this respect: it occurred in each of the decades between 1911 and 1955, and resulted from conceptions at the onset of 
the rainy season just after the period when the water in the reservoirs was at its lowest.

Again, there is no significant relationship between seasonal variation in sex ratio and seasonal variation in total births registered, although the 2 months with lowest sex ratios (December and January) also have the lowest number of birth registrations. There has been no appreciable seasonal variation in sex ratio since the water supply was augmented from the Murray in 1955.

\section{Brisbane, Queensland}

In contrast to those of Adelaide and Perth, the wet season in Brisbane begins in mid-November and finishes in a rather indeterminate way between April

TABLE 3

AGGREGATED MONTHLY REGISTRATIONS OF LIVE BIRTHS FOR THE METROPOLITAN DIVISION OF SOUTH AUSTRALIA $†$ FOR THE YEARS 1911 TO 1955

\begin{tabular}{l|c|c|c}
\hline & Male births & Female births & $\begin{array}{c}\text { Sex ratio } \\
\text { (female }=100)\end{array}$ \\
\cline { 1 - 2 } January & 10894 & 10558 & $102 \cdot 9$ \\
February & 11753 & 10876 & $108 \cdot 0^{*}$ \\
March & 12944 & 12338 & $104 \cdot 9$ \\
April & 11666 & 10762 & $108 \cdot 4^{*}$ \\
May & 12777 & 11918 & $107 \cdot 2^{*}$ \\
June & 12642 & 11676 & $108 \cdot 3^{*}$ \\
July & 12119 & 11411 & $105 \cdot 9$ \\
August & 12357 & 11876 & $104 \cdot 1$ \\
September & 13000 & 12224 & $106 \cdot 4$ \\
October & 12814 & 12083 & $106 \cdot 1$ \\
November & 12334 & 11831 & $104 \cdot 3$ \\
December & 10557 & 10238 & $103 \cdot 1$ \\
Total & 145857 & 137791 & $105 \cdot 9$ \\
\hline
\end{tabular}

† Adelaide is the largest component of this division.

* The sex ratio for these months combined differs significantly from that of the other 8 months $(P<0.01)$.

and June (Table 1, Text-fig. 1). In recent years, there has been an increasing tendency, not clearly shown in the averages for 1911 to 1940, for the boundary of the southern winter rains to spread into southern Queensland during May, June and July.

During the years 1951 to 1962 , the sex ratio for the months of November and December was significantly higher $(P<0.001)$ than for the rest of the year (Table 4). These high sex ratios result from conceptions in February and March, that is from about 10 weeks to about 18 weeks after the onset of the rainy season (Text-fig. 1). The lowest sex ratio was recorded for September (conception month, December). There is no evidence of any relationship between sex ratio and the number of births registered. Seasonal variations in sex ratio in Brisbane are, however, not apparent before 1951. There is evidence, moreover, that the annual sex ratio has not been constant throughout the period 1911 to 1962. The mean sex ratio for the 28 years 1925 to 1952 was lower than those for the preceding 14 years and for the subsequent 10 years (Table 5 ). Within 
each of these three periods, annual sex ratios varied little, and from 1925 to 1952 only 5 years had a sex ratio above $106: 100$. The differences in annual sex ratio between the three periods accompanied changes in the management of the Brisbane water supply, especially the extent of chlorination, a factor which might well affect drinking habits. Water from the Brisbane river was

TABLE 4

AGGREGATED MONTHLY REGISTRATIONS OF LIVE BIRTHS FOR THE METROPOLITAN DIVISION OF QUEENSLAND $†$ FOR THE YEARS 1951 To 1962

\begin{tabular}{l|c|c|c}
\hline & Male births & Female births & $\begin{array}{c}\text { Sex ratio } \\
\text { (female }=100)\end{array}$ \\
\hline January & 5264 & 5268 & $106 \cdot 8$ \\
February & 5202 & 4961 & $104 \cdot 8$ \\
March & 5758 & 5474 & $105 \cdot 2$ \\
April & 5350 & 5013 & $106 \cdot 6$ \\
May & 5877 & 5461 & $107 \cdot 6$ \\
June & 5483 & 5136 & $106 \cdot 8$ \\
July & 6097 & 5776 & $105 \cdot 6$ \\
August & 6084 & 5707 & $106 \cdot 6$ \\
September & 5929 & 5724 & $103 \cdot 6$ \\
October & 6184 & 5747 & $107 \cdot 6$ \\
November & 5769 & 5088 & $113 \cdot 4 *$ \\
December & 5321 & 4838 & $109 \cdot 8 *$ \\
Total & 68318 & 64193 & $106 \cdot 4$ \\
& & & \\
\hline
\end{tabular}

$\dagger$ Brisbane is the largest component of this division.

* The sex ratio for these months combined differs significantly from that of the other 10 months $(P<0.001)$.

TABle 5

CHANGES IN SEX RATIO FOR THE METROPOLITAN DIVISION OF QUEENSLAND DURING THREE PERIODS BETWEEN THE YEARS 1911 AND 1962

\begin{tabular}{c|c}
\hline Period of registration & $\begin{array}{c}\text { Sex ratio } \\
\text { (female }=100)\end{array}$ \\
\hline 1911 to 1924 & $106 \cdot 4$ \\
1925 to 1952 & $105 \cdot 2^{*}$ \\
1953 to 1962 & $106 \cdot 8^{* *}$ \\
\hline
\end{tabular}

* This ratio differs significantly from that of 1911 to $1924(P<0.05)$

** This ratio differs significantly from that of 1925 to $1952(P<0.01)$.

first chlorinated at the end of 1923. From 1923 to the end of 1947, flocculation and filtration were inadequate, the water was very muddy during the wet season and chlorination was sometimes as high as $5 \mathrm{ppm}$. After new filter beds were installed in 1947 and 1954, chlorination was progressively reduced and since 1954 has not exceeded $1.5 \mathrm{ppm}$. Furthermore, before the construction of 
the Somerset Dam, Brisbane had no proper reservoir: this dam came into partial use in 1943 and was completed in 1954.

Sydney, New South Wales

Rainfall in Sydney is more evenly distributed throughout the year than in the other three cities, and the mean monthly rainfall does not fall below 2.4 in. (Table 1, Text-fig. 1). The aggregated monthly birth registrations for the

TABLE 6

AGGREGATED MONTHLY REGISTRATIONS OF LIVE BIRTHS FOR THE METROPOLITAN DIVISION OF NEW SOUTH WALES† FOR THE YEARS 1911 TO 1962

\begin{tabular}{l|c|c|c}
\hline & Male births & Female births & $\begin{array}{c}\text { Sex ratio } \\
\text { (female =100) }\end{array}$ \\
\hline January & 57799 & 55378 & $104 \cdot 4$ \\
February & 53964 & 50868 & $106 \cdot 1$ \\
March & 56950 & 54438 & $104 \cdot 6$ \\
April & 54637 & 51734 & $105 \cdot 6$ \\
May & 58479 & 55662 & $105 \cdot 1$ \\
June & 55585 & 53193 & $104 \cdot 5$ \\
July & 58902 & 56190 & $104 \cdot 8$ \\
August & 58392 & 56057 & $104 \cdot 2$ \\
September & 57607 & 54811 & $105 \cdot 1$ \\
October & 60461 & 57468 & $105 \cdot 5$ \\
November & 56996 & 53819 & $105 \cdot 9$ \\
December & 53437 & 50475 & $105 \cdot 9$ \\
Total & 683389 & 650093 & $105 \cdot 1$ \\
\hline
\end{tabular}

$\dagger$ Sydney is the largest component of this division.

TABLE 7

AGgREgATED REgISTRATIONS OF LIVE BIRTHS FOR MONTHS FALLING 11 MONTHS AFTER HIGH RAINFALL MONTHS (DESIGNATED MANIFESTATION MONTHS) AND FOR THE REMAINING MONTHS, FOR THE METROPOLITAN DIVISION OF NEW SOUTH WALES DURING THE YEARS 1910 TO 1961

\begin{tabular}{l|c|c|c|c}
\hline & $\begin{array}{c}\text { No. } \\
\text { months }\end{array}$ & $\begin{array}{c}\text { Male } \\
\text { births }\end{array}$ & $\begin{array}{c}\text { Female } \\
\text { births }\end{array}$ & $\begin{array}{c}\text { Sex ratio } \\
\text { (female=100) }\end{array}$ \\
\hline $\begin{array}{c}\text { Manifestation months } \\
\text { Remaining months }\end{array}$ & 222 & $\begin{array}{l}250726 \\
432663\end{array}$ & $\begin{array}{c}237000 \\
413093\end{array}$ & $\begin{array}{c}105 \cdot 8^{*} \\
104 \cdot 7^{*}\end{array}$ \\
\hline
\end{tabular}

* These ratios differ significantly from one another $(P<0.01)$.

51 -year period 1910 to 1960 correspondingly show only small seasonal variations in sex ratio (Table 6, Text-fig. 1). Nevertheless, an association between rainfall and sex ratio does become apparent when the figures are analysed in terms of wet months and dry months, and, since 1948, of wet years and dry years. Between 1910 and 1961, there were 222 months with a rainfall exceeding $3.5 \mathrm{in}$. In the months falling 11 months after each of these 222 months, there 
was a significantly higher sex ratio $(P<0 \cdot 01)$ than in the other 402 months (Table 7). During the same period, there were thirty-five occasions when drought or near-drought for 3 months or more was followed by at least $5 \mathrm{in}$. of rain: the average sex ratio for the 11 th month after each of these occasions was $107: 100$. The Commonwealth Yearbooks record twenty-three dates since 1910 when phenomenally large rainfalls occurred at places sufficiently close to influence the catchment area of Sydney: the birth registrations for the months 11 months later give an average sex ratio again of $107: 100$. From 1948 to

TABLE 8

ANNUAL RAINFALL REGISTRATIONS FOR SYDNEY FOR THE YEARS 1948 TO 1961

\begin{tabular}{l|l||l|l}
\hline Year & $\begin{array}{c}\text { Rainfall } \\
\text { (in.) }\end{array}$ & rear & $\begin{array}{l}\text { Rainfall } \\
\text { (in.) }\end{array}$ \\
\hline 1948 & $38 \cdot 83$ & $1956^{*}$ & $67 \cdot 33$ \\
$1949^{*}$ & 66.26 & 1957 & $27 \cdot 13$ \\
$1950^{*}$ & 86.33 & $1958^{*}$ & $59 \cdot 19$ \\
1951 & 53.15 & $1959^{*}$ & $59 \cdot 67$ \\
$1952^{*}$ & 59.19 & 1960 & 51.01 \\
1953 & $40 \cdot 86$ & $1961^{*}$ & 57.08 \\
1954 & 41.29 & & \\
$1955^{*}$ & 72.46 & Mean & $55 \cdot 67$ \\
\hline
\end{tabular}

* Years in which the mean rainfall of 55.67 in. was exceeded.

TABle 9

ANNUAL SEX RATIOS FROM REGISTRATIONS OF LIVE BIRTHS FOR THE METROPOLITAN DIVISION OF NEW SOUTH WALES FOR THE YEARS 1949 TO 1962

\begin{tabular}{l|c||c|c}
\hline rear & $\begin{array}{c}\text { Sex ratio } \\
\text { female }=100)\end{array}$ & rear & $\begin{array}{c}\text { Sex ratio } \\
\text { female }=100)\end{array}$ \\
\hline 1949 & $104 \cdot 38$ & $1957^{*}$ & $106 \cdot 00$ \\
$1950^{*}$ & $106 \cdot 05$ & 1958 & $103 \cdot 07$ \\
$1951^{*}$ & $106 \cdot 24$ & $1959^{*}$ & $106 \cdot 64$ \\
1952 & $104 \cdot 27$ & $1960^{*}$ & $105 \cdot 77$ \\
$1953^{*}$ & $104 \cdot 80$ & 1961 & $104 \cdot 45$ \\
1954 & $106 \cdot 33$ & $1962^{*}$ & $106 \cdot 01$ \\
1955 & $104 \cdot 58$ & Simple mean & $105 \cdot 39$ \\
$1956^{*}$ & $107 \cdot 00$ & & \\
\hline
\end{tabular}

* Years after years in which the mean rainfall of 55.67 in. was exceeded. These are the 'manifestation years' of Table 10 .

1961 , there were 8 years in which the average rainfall of $55.67 \mathrm{in.}$ was exceeded (Table 8). With one exception (1953), the years following each of these years had sex ratios above the simple average $(105 \cdot 35: 100)$, whereas, again with one exception (1954), the remaining 6 years had sex ratios below the simple average. Further, the year with the lowest sex ratio (1958) followed the year of lowest rainfall (Table 9). The aggregated birth registrations for these two sets of years show a significant difference in sex ratio (Table 10). 
Areas of Australia with trace-element deficiencies

Birth registrations have also been examined for two areas of Australia considered to be deficient in trace elements such as copper, zinc, molybdenum, sulphur and boron. These are the Tablelands of New South Wales, which

TABLe 10

AGGREGATED REGISTRATIONS OF LIVE BIRTHS FOR YEARS FOLLOWING YEARS OF GREATER THAN AVERAGE RAINFALL (DESIGNATED MANIFESTATION YEARS) AND FOR THE REMAINING YEARS, FOR THE METROPOLITAN DIVISION OF NEW SOUTH WALES DURING THE YEARS 1949 TO 1962

\begin{tabular}{l|c|c|c|c}
\hline & $\begin{array}{c}\text { No. } \\
\text { years }\end{array}$ & $\begin{array}{c}\text { Male } \\
\text { births }\end{array}$ & $\begin{array}{c}\text { Female } \\
\text { births }\end{array}$ & $\begin{array}{c}\text { Sex ratio } \\
\text { (female }=100)\end{array}$ \\
\hline Manifestation years & 8 & 148100 & 139594 & $\begin{array}{c}106 \cdot 09^{*} \\
104 \cdot 49^{*}\end{array}$ \\
\hline Remaining years & 6 & 108988 & 104308 & \\
\hline
\end{tabular}

* These ratios differ significantly from one another $(P<0.01)$.

TABLE 11

REGISTRATIONS OF LIVE BIRTHS FOR LOCAL GOVERNMENT AREAS WITH LOW SEX RATIOS IN THE TABLELANDS OF NEW SOUTH WALES FOR THE YEARS 1927 TO 1962

\begin{tabular}{|c|c|c|c|}
\hline & $\begin{array}{l}\text { Male } \\
\text { births }\end{array}$ & $\begin{array}{c}\text { Female } \\
\text { births }\end{array}$ & $\begin{array}{c}\text { Sex ratio } \\
(\text { female }=100)\end{array}$ \\
\hline $\begin{array}{l}\text { Municipaurties } \\
\text { Bombala } \\
\text { Cooma } \\
\text { Goulburn } \\
\text { Camden }\end{array}$ & $\begin{array}{r}619 \\
2000 \\
6422 \\
927\end{array}$ & $\begin{array}{r}612 \\
1979 \\
6254 \\
908\end{array}$ & $\begin{array}{l}101 \cdot 1 \\
101 \cdot 1 \\
102 \cdot 7 \\
102 \cdot 1\end{array}$ \\
\hline $\begin{array}{l}\text { SHIRES } \\
\text { Cudgegong } \\
\text { Abercrombie } \\
\text { Cockburn } \\
\text { Bibbenluke } \\
\text { Guyra } \\
\text { Lyndhurst } \\
\text { Merriwa } \\
\text { Molong } \\
\text { Manilla } \\
\text { Peel } \\
\text { Snowy River } \\
\text { Tallaganda } \\
\text { Wingecarribbee } \\
\text { Wollondilly }\end{array}$ & $\begin{array}{l}1628 \\
1289 \\
1989 \\
1225 \\
2985 \\
2624 \\
1238 \\
1943 \\
1046 \\
2787 \\
1840 \\
1052 \\
2475 \\
3178\end{array}$ & $\begin{array}{l}1654 \\
1320 \\
1988 \\
1219 \\
2954 \\
2618 \\
1264 \\
1945 \\
1043 \\
2782 \\
1822 \\
1120 \\
2457 \\
3122\end{array}$ & $\begin{array}{r}98.4 \\
97.7 \\
100 \cdot 1 \\
100 \cdot 5 \\
101 \cdot 0 \\
100 \cdot 2 \\
97.9 \\
99.9 \\
100 \cdot 3 \\
100 \cdot 2 \\
101.0 \\
93.9 \\
100.7 \\
101.8\end{array}$ \\
\hline Total & 37267 & 37061 & $100 \cdot 6$ \\
\hline
\end{tabular}

extend from the Queensland border to the Victoria border, and a large part of the agricultural region in south-west Western Australia.

Birth registrations for New South Wales, published by municipality and shire, are available from 1916 (Statistical Registers for New South Wales). Up to 1926, however, births were classified according to the actual place of birth, and 
the records are heavily biased in favour of towns with maternity hospitals. From 1927, births have been classified according to the usual residence of the mother, but analyses of the records remain difficult because of changes in the boundaries of the registration areas. The total birth registrations for the period 1927 to 1962, in eighteen areas that have remained substantially unchanged in respect of boundary and sources of water, are given in Table 11 . These registrations, which are well distributed throughout the 36 -year period, show consistently low sex ratios in all eighteen areas and a mean sex ratio of 100.6:100. The simple average sex ratio for Australia as a whole, for the years 1927 to 1963 , is $105 \cdot 3: 100$.

There are ninety-five local government areas in the agricultural region of south-west Western Australia. Published birth registrations for these areas are available from 1953 (Statistical Registers for Western Australia). These records show that forty-nine areas all have an excess of female births for the 10 years 1953 to 1962 (total registrations, 13,674 males and 13,907 females; sex ratio $98 \cdot 3: 100)$.

It is also relevant that annual birth registrations from 1911 consistently show that the rural areas of Australia have a lower sex ratio than the metropolitan areas. Roof water stored in tanks is the usual source of drinking water on farms throughout the country, and probably less than half the rural population has a water supply derived from surface catchment areas.

\section{DISGUSSION}

The observations for Perth (1941 to 1962), Adelaide (1911 to 1955) and Brisbane (1951 to 1962) give clear evidence of systematic seasonal variations in secondary sex ratio. These variations, though reasonably consistent between years within cities, do not fall in the same season in different cities. They do, however, become consistent between cities when considered in relation to seasonal variations in rainfall. In each city, a significantly greater proportion of males is found among newborn children conceived from about 6 to 10 weeks to about 18 to 20 weeks after the onset of the rainy season. The only serious exception occurs in Adelaide, where there is an additional significant increase in sex ratio for babies conceived in May, during the very beginning of the rainy season. No explanation can be given for this anomaly, but its existence should not be overlooked.

Seasonal changes in sex ratio were not, however, consistent in any of the three cities throughout the entire period for which records are available (1911 to 1962); but, in each city, the differences between groups of years were accompanied by changes in the management of the local water supply. In Adelaide, the seasonal changes largely disappeared after 1955, when the local catchment source of drinking water was first supplemented with water from the River Murray. In Perth, no seasonal variations were apparent before 1940, during the years when artesian sources of water were extensively used. In Brisbane, there is evidence of a fall in sex ratio for the years 1925 to 1952, when high levels of chlorination prevailed and may have led to changes in drinking habits.

The observations for Sydney, where rainfall is heavier and more evenly 
distributed throughout the year than at Perth, Adelaide or Brisbane, show no marked seasonal pattern of sex ratio variation. However, months with greater than average rainfall tend to be followed 11 months later by months with higher than average sex ratios and years with greater than average rainfall tend to be followed by years of greater than average sex ratio. This reveals a similarity between Sydney and the other three cities.

These observations all suggest that there is a causal relationship between rainfall and sex ratio in areas of Australia with a local surface catchment source of drinking water. The turbidity of the water in the reservoirs varies markedly between wet seasons and dry seasons, and is highest during the first rains. It is suggested that some property of drinking water associated with this seasonal cycle influences sex ratio, and that the property most likely to be concerned is its content of trace elements. If this hypothesis is true, one would expect to find regional differences in sex ratio associated with differences in the chemical nature of soil and rock over which drinking water is collected and locallyproduced food is grown. Records for the Tablelands of New South Wales and the agricultural region of south-west Western Australia, where certain trace element deficiencies are reported (McLachlan, 1955; Weir, Partridge \& Fawcett, 1956; Spencer \& Barrow, 1963; C.S.I.R.O., personal communications), do indeed suggest that unusually low sex ratios prevail in these areas.

The observations for Perth, Adelaide and Brisbane suggest that the rains first influence sex ratio in pregnancies conceived about 6 to 10 weeks after the onset of the rains. If the observed increases in sex ratio arise from increases in the relative viability of male embryos, the lag of 6 to 10 weeks is difficult to explain. If, however, they arise from an increase in primary sex ratio caused by an increase in the number or effectiveness of $\mathrm{Y}$-spermatozoa, the lag period may be accounted for as the time required for the changes in spermatozoa to appear in the ejaculate.

According to Heller \& Clermont (1963), the time elapsing between the production of a new stem-cell spermatogonium and the release of its descendant spermatozoa from the testis in man is a little more than 64 days. Probably a further 2 to 5 weeks are required for the spermatozoa to pass through the ductus epididymis to the ejaculate. This gives an estimated total of 11 to 14 weeks. Whilst events that differentially affect the numbers or properties of $\mathrm{X}$ - and $\mathrm{Y}$-spermatozoa could occur during any part of this period, the most likely time is during the early post-meiotic stages of spermatogenesis, when the segregation of $\mathrm{X}$ - and $\mathrm{Y}$-chromosomes is complete, the spermatids are undergoing extensive reorganization, and losses of cells appear to be considerable (see Bishop \& Walton, 1960). This would be from about 24 days before release from the testis, or from about 5.5 to 8.5 weeks before arrival in the ejaculate. This estimate fits the observed lag period fairly well.

The suggested causal relationship between trace elements and sex ratio is, of course, far from proven, but it does provide a plausible explanation of the observations here reported. Perhaps it will be found to apply, through underlying dietary causes, to other instances of variation in sex ratio, such as those associated with social class, race and war. In any event, the hypothesis suggests lines for further analysis and experiment. 
ADDENDUM

The rainfall for Sydney in 1962 was 44.90 in.; the sex ratio in 1963 was $104 \cdot 94: 100$.

\section{ACKNOWLEDGMENTS}

We are greatly indebted to those who have supplied us with information and to Professor A. S. Parkes, C.B.E., F.R.s., for his interest and encouragement.

\section{REFERENCES}

Bishop, M. W. H. \& WALton, A. (1960) Spermatogenesis and the structure of mammalian spermatozoa. Marshall's Physiology of Reproduction, 3rd edn, vol. 1, pt. 2, p. 1. Ed. A. S. Parkes. Longmans Green, London.

Colomвo, B. (1957) On the sex ratio in man. Cold Spr. Harb. Symp. quant. Biol. 22, 193.

CREw, F. A. E. (1952) The factors which determine sex. Marshall's Physiology of Reproduction, 3rd edn, vol. 2, p. 741. Ed. A. S. Parkes. Longmans Green, London.

Heller, C. G. \& Glermont, Y. (1963) Spermatogenesis in man: an estimate of its duration. Science, 140, 184.

McLachlan, K. D. (1955) Phosphorus, sulphur and molybdenum deficiencies in soils of eastern Australia. Austr. J.agric. Res. 6, 673.

Spencer, K. \& Barrow, N. J. (1963) Survey of the plant nutrition status of principal soils on the northern tablelands of New South Wales. Tech. Paper No. 19, Division of Plant Industry, C.S.I.R.O., Australia.

Weir, R. G., Partridge, F. \& Fawcett, R. G. (1956) Minor element trials in New South Wales plant nutrition survey. N.S.W. agric. Gaz., January. 